\title{
THE RELATIONSHIP BETWEEN EMPOWERMENT AND PERFORMANCE IN THE CITY COUNCIL OF NAIROBI
}

\author{
Stephen N. M Nzuve, Tsala Halima Bakari \\ University of Nairobi, Kenya \\ E-mail: snmnzuve@uonbi.ac.ke
}

\begin{abstract}
Local authorities in Kenya have been known for poor performance. In the recent past, the trend has changed due to the introduction of performance contracting where employees must set and meet work targets from their supervisors, hence the need to be enabled to perform. The local authorities' service provision would be largely improved with the implementation of employee empowerment within the local authorities. This study sought to establish the extent to which the City Council of Nairobi (CCN) had put in place employee empowerment programs and also to determine the relationship between employee empowerment practice and the performance of the City Council of Nairobi. In view of the above, a case study design was deemed appropriate to fulfill the objectives of the study, since data for research was obtained from one organization.

The population of interest comprised all the employees of the City Council of Nairobi which was picked owing to the fact that it is the largest local authority in Kenya and is therefore expected to engage in the best human resource practices.

A sample of 60 employees, 4 from each of the 15 departments comprised the respondents who were selected randomly. The study used both primary and secondary data. The primary data was collected through a structured questionnaire administered on drop and pick basis. Data on performance as measured by return on assets (ROA) was collected from secondary sources. The analysis was done mainly using descriptive statistics such as mean scores, frequencies and percentages. Pearson product moment correlation technique was used to establish the strength and significance of the relationship between empowerment and performance. Findings of this study reveal that the employee empowerment score in the City Council of Nairobi indicate that the employees are empowered to a large extent. This is demonstrated by an average score of 3.546. The study also found that there is a very strong positive correlation between employee empowerment and performance. The study concluded that employee empowerment had a great positive influence on the performance of the City Council of Nairobi.

Key words: performance contracting, employee empowerment, business process reengineering, total quality management, performance management, local authority, return on assets, performance.
\end{abstract}

\section{Introduction}

Employee empowerment is a strategy and philosophy that enables employees to make decisions about their jobs, own their work and take responsibility for their results as well as serve customers at the level of the organization where the customer interface exists. The concept of employee participation has been a topic for research and of interest to employers for many years. It has taken many different forms, evolving from employee involvement and participative decision-making concepts to the contemporary empowerment perspective. The notion of empowerment involves the workforce being provided with a greater degree 
PROBLEMS

OF MANAGEMENT

IN THE $21^{\text {st }}$ CENTURY

Volume 5, 2012

84 with traditional management techniques that have emphasized control, hierarchy and rigidity. The meaning of empowerment has tended to be associated with the concept of power, thereby implying that power is redistributed by those in a senior position to those in more subordinate positions (Tulloch, 1993).

Whilst accounts of the supposed advantages of empowerment, still remains a poorly defined concept, which is frequently used in a rhetorical sense (Mondros and Wilson, 1994). Empowerment is the process of enabling or authorizing an individual to think, behave, and take action, and control work and decision making in autonomous ways. It is the state of feeling confident to take control of one's own destiny (Heathfield, 2007).

The meaning of empowerment has been the subject of great debate, but still remains poorly defined (Dainty et al., 2002). Mondros and Wilson (1994), and Russ and Millam (1995), similarly argued that the term is rarely defined clearly and is frequently used rhetorically. One possible reason for this lack of clarity is the tendency for empowerment to be attached to management concepts, for example, business process re-engineering (BPR) and total quality management (TQM) (Dainty et al., 2002). Furthermore, the term empowerment represents a wide variety of activities, from "sham" empowerment (Rosenthal et al., 1997) to a high level of involvement and devolution of power. Wilkinson (1998) identified five types of empowerment: information sharing; upward problem solving; task autonomy; attitudinal shaping; and selfmanagement.

The original meaning of empowerment has been referred to as authors, give power to" (Tulloch, 1993). The use of the term "power" appears to be common throughout the definitions of empowerment; for example, Legge (1995) argued that empowerment should be seen in terms of a redistribution model whereby power equalization is promoted for trust and collaboration. Similarly, Cogner and Kanungo (1998), focused on power as the central point of empowerment, "either to strengthen this belief or to weaken belief in personal powerlessness". Power is often redistribution by transferring control so that employees have the authority to make and implement their own decisions. Conger and Kanungo (1998), make a distinction between the relational and motivational meanings of empowerment. The relational aspect examines the relationship between the managers and workers both before and after empowerment. The motivational dimension suggests a process through which initiative will need to pass for employees to feel motivated. Other authors in the field define empowerment in terms of its dynamic interaction, for example Pastor $(1996$, p. 5) stated that: "it is part of a process or an evolution - an evolution that goes on whenever you have two or more people in a relationship, personally or professionally". Lee and Koh (2001) refined this description further by looking at the inter-subjective nature of the subordinate and supervisor. They stated that empowerment is the combination of the psychological state of a subordinate, which is influenced by the empowering behaviors of supervisors.

Organizations are increasingly looking at employee empowerment as a unique asset that can improve performance and provide sustained competitive advantage. The changes in the business environment with increasing globalization, changing demographics of the workforce, increased focus on profitability through growth, technical changes, intellectual capital and the never-ending changes that organizations are undergoing have led to increased importance of employee empowerment (Wright, 1998). For any organization to function efficiently and effectively, a number of resources have to be employed. For example, physical facilities like buildings, machinery; financial resources and human resources.

The component of human capital is very crucial for any meaningful development in an organization. For example, to increase productivity you have to deal with people and to increase efficiency you need to work on the attitude and skills of your employees. Thus for people to perform well they have to be enabled through skills development and conducive environment for learning and development (Wright, 1998). 
Everyone in the organization from top to bottom, from offices to technical service, from

\author{
PROBLEMS \\ OF MANAGEMENT \\ IN THE $21^{\text {st }}$ CENTURY \\ Volume 5, 2012
}

headquarters to local sites must be involved. People are the source of ideas and innovation and their expertise, experience, knowledge and co-operation have to be harnessed to get these ideas implemented (Dale, 2004:181). Employees are the core ingredients of service products. Because minimal time separates the production of the service from its delivery, the idea of providing workers the flexibility, latitude and ability to meet customer service demands is intuitively appealing thus it is not surprising that more service organizations are embracing employee empowerment programs. (Enz\&Siguaw, 2000; Tabarda, 2000).

\title{
Performance
}

Performance management is concerned with actions taken to improve performance in order to achieve organizational, team or individual effectiveness. Improving performance is only achievable where there are effective processes of continuous development. This in turn addresses the core competencies of the organization and the capabilities of individuals and teams (Lawson, 1995).

Performance management is the principal set of practices by which control is manifested in organizations. Control is defined as any process that is used to align actions of individuals to the interests of the organizations (Snell, 2006). Performance management is expected to regulate motivation and ability. It is a cybernetic system with feedback from both employee driving modifications at each point in the system.

Since performance management is concerned with satisfying the needs and expectations of various stakeholders such as owners, management, employees, customers, suppliers and the general public, employees should be treated as partners in the enterprise whose interests are respected. To this end, Performance Management encourages communication and involvement of managers and their team members in defining expectation and sharing information on the organization's mission, values and objectives (Lawson, 1995).

\section{Empowerment and Performance}

Most of the studies that relate empowerment and performance use an individual level of analysis, typically focusing on the association between job design and task performance. Little is known of the relationship between job enrichment and company performance (Patterson et al, 2004). This is an important omission, as several of the potential benefits of job enrichment may occur at the organizational level. For example, lower cost from a reduction in a supervisory, engineering, and other support staff are important at an organizational level of analysis but would not register in a measure of task performance.

Research on the effectiveness of human resources management (HRM) practices to some extent mitigates the above problem. Measures of HRM typically encompass job enrichment and skill enhancement, and studies have found HRM to be positively associated with company performance (Guthrie, 2001). In research, HRM is typically measured as a multi-dimensional construct covering a wide range of different practices additional to those of current interest (for instance, performance and profit-related pay, harmonization).

More direct support for the importance of empowerment to firm performance is provided by Huii, Bierman, Shimizu, and Kochhar's (2001) study, who found a positive relationship between human capital (based on intellectual capabilities, knowledge, and social capital) and firm performance in a sample of professional organizations.

In another study, Hechanova et al. (2006) did a study on the relationship between psychological empowerment, job satisfaction and performance among Filipino service. The study found that psychological empowerment was positively correlated with performance. 
PROBLEMS

OF MANAGEMENT

IN THE $21^{\text {st }}$ CENTURY

Volume 5, 2012

86

Although there are few empirical tests of the impact of empowerment practices on company performance, there are strong conceptual grounds for arguing that each initiative will contribute to company performance, and it is precisely because they should do so that they have proved so attractive to companies.

\section{The Relationship between Employee Empowerment and Performance}

Performance management is linked to employee empowerment in two ways; First, through goal setting. The more an employee understands his or her job, and how the job contributes to the overall organization, the better they will be able to make decisions on their own, informed and expert decisions. Employee empowerment requires this clarity, or the decisions that get made will often be the wrong ones. Second, empowerment implies accountability, along with the freedom to make decisions. The performance management process helps to ensure that accountability for results and the outcomes of decisions the employee makes through ongoing communication, and of course, the performance review process.

There is limited research on the relationship between employee empowerment and performance. Most of the available literature on employee empowerment has linked to it job satisfaction. There are vast studies done on the relationship between job satisfaction and employee empowerment. Thus, job satisfaction often has an intervening effect between employee empowerment and performance.

One of the studies that provide direct support for the relationship between empowerment and firm performance is provided by Hitt, Bierman, Shimizu, and Koachhar's (2001). This study found a positive relationship between human capital (based on intellectual capabilities, knowledge, and social capital) and firm performance in a sample of professional organizations.

Another study that makes a possible link between empowerment and performance was bone by Hechonova et al. (2006) on the relationship between psychological empowerment, job satisfaction and performance among Filipino service workers. The study found that psychological empowerment had a positive correlation with performance.

Wood (2007) also did a study which found that employee empowerment was the key to improving performance and promoting innovation among manufacturing firms in Ireland. The study found that empowerment is the only practice that has significant effects on performance in all companies surveyed. The study found that performance in companies that empowered their employees was $7 \%$ higher than that of companies that did not empower their employees.

\section{The Potential Benefits of Empowerment}

The espoused benefits of empowerment can be broadly divided into two areas: benefits for the organization and benefits for the individual. Much of the research into empowerment has focused on organizational benefits assuming these are the driving force behind attempts to endanger empowered working (Cunningham et al., 1996)

Global competition and a changing business environment have instigated organizational change in response to increased pressures to improve efficiency and performance (Lawler et al., 1992). Specifically organizations have sought improvements in various economic performance areas (Applebaum et al., 1999). However, measurement of the economic benefits of empowerment specifically may be difficult as often it is introduced as part of a broader initiative such as BPR and TQM (Psoinos and Smithson, 2002).

While the primary motive of empowerment is usually to improve the economic performance of the organization, benefits to the individual employee have also been identified. Nykodym et al. (1994) found that employees who consider themselves empowered have 
reduced conflict and ambiguity in their role, as they are able to control (to a certain extent) their

own environment. They suggested that this reduces the emotional strain on their employees.

On a similar theme, it was reported that empowered employees have a greater sense of job satisfaction, motivation and organizational loyalty (Mullins and Peakock, 1991), as they feel more involved in the achievement of the organizational goals. Despite these benefits frequently cited, the nature and meaning of this job satisfaction and motivation have not been fully explored within the academic field.

Measurement of the employee benefits is very difficult to achieve. Unlike organizational benefits which can be measured using objective "facts", individual benefits are much more subjective and complex. Certain factual measures, such as absence and turnover rates have been applied in this aim, as too have the Investors in People awards which can be used as an indirect indicator of the company's commitment to the development skills (Psoinos and Smithson, 2002). However, it is often considered that softer measures of employee 'attitudes may be more appropriate than those "objective" measures (Psoinos and Smithson, 2002)

Managers are faced with many difficulties when attempting to empower employees and these may prevent a business from becoming and empowering organization. First, there is often resistance to the change both from managers/leaders and from employees themselves. It is often assumed that employees will buy into empowerment, as the benefits are "obvious". However, this has been disputed by Johnson (1994) who claims that previously disempowered employees may resist empowerment, as they fear the increased levels of responsibility and accountability. Further, employees may consider empowerment to be just empty rhetoric and yet another management attempts to exploit them. Alder (1993) demonstrated that empowerment is linked to downsizing as frequently those two activities occurred simultaneously. Therefore, it is hardly surprising that employees are suspicious of management schemes.

Managers/leaders may also be resistant to empowerment for this may be perceived as relinquishing power. They may view the reduction of their power as a threat (Denham et al., 1997), particularly as they too fear job loss or loss of status as the organizational structures become flatter during the downsizing process. They may also vary in their inclination to introduce empowerment in spite of its being a component of organizational policy.

The gap between rhetoric and practice is a further area that is open to criticism. A number of studies have identified that, in some instances, the problems encountered are present in name only (Harold, 1997). While this is not a barrier to empowerment per se, it can lead to inaccurate criticisms of the empowerment concept and more importantly, those who are empowered may be disillusioned and reject empowerment as ineffective. Furthermore, it is important that those who incorporate and empowerment strategy do not believe that it will solve all organizational problems; if they do they will ultimately be disappointed.

\section{An Overview of the City Council of Nairobi}

Nairobi was made a Municipality in 1935 by a Charter given by the Queen of England before the independence of Kenya in 1963. The City Council of Nairobi (CCN) was set up in 1952 and its function is to deliver services to the residents of Nairobi and maintain the City status of Nairobi. CCN derives its legal mandate form the Local Government Act (Cap 265) of the Laws of Kenya amongst other Act of Parliament that augment its diverse core functions and priorities (CCN Hand book, 2007).

These priorities are contained in various policies and planning documents such as the National Development plans, Poverty Reduction Strategy Paper and Economic Recovery Strategy (ERS) for Wealth and Employment Creation in the medium term of Kenya's vision 2030 \& the Millennium Development Goals (MDG's) in the long term (CCN Handbook, 2007). 
PROBLEMS

OF MANAGEMENT

IN THE $21^{\text {st }}$ CENTURY

Volume 5, 2012

88

The council is mandated to provide and manage basic social and physical infrastructure, services to the residents of Nairobi. These services include basic education, housing, health, water and sewerage, refuse and garbage collection, planning and development control, urban public transport and fire fighting services among others (CCN Handbook, 2007).

The department of Human Resources was formed in the year 2000 after the Mbogua Extra-ordinary Inspection Team recommended the upgrading of the establishment section to a fully fledged department. This recommendation was approved by the Minister of Local Government. In February 2003, the Minister of Local Government deployed a personnel officer to the Council with the mandate of assisting the Town Clerk in setting up effective measures within the Council, identifying weaknesses in staffing and deployment procedures, suggesting optimum staffing within the department among others (CCN Handbook, 2007).

In order to operationalize the department, the Directorate of Personnel Management deployed an officer to perform the duties of the Director Human Resource Management with the mandate to undertake a reconciliation of the Council's establishment, reviewing the disciplinary code and establishing modern human resource practices, improving performance management practices through selection, promotion and retention of staff, reviewing the Collective Bargaining Agreement (CBA) with a view of removing anomalies and contradictions with the Services Commission Act among other responsibilities. The Human Resource Department is now fully operational and is headed by a Director, an appointee of the Public Service Commission (CCN Statement of the Problem Handbook, 2007).

\section{Statement of the Problem}

Human Resource is one of the most critical capital to any organization be it labour or capital intensive. The physical resources such as land, machinery and finance require competent human resources for them to operate efficiently and effectively. Thus, development and success of any organization requires involvement of all its employees as they pursue organizational objectives. The vision and mission of companies give direction to all employees as they pursue organizational objectives. Local authorities in the countries have been known for poor performance(http://en.wikipedia.org/wiki/Nairobi_City_Council).In recent times, the trend has changed due to the introduction of performance contracting where employees must meet performance targets from their supervisors, hence the need to be enabled to perform. The local authorities' service provision would be largely improved with the implementation of employee empowerment in the local authorities.

A number of studies have been done on employee empowerment. For instance, Odongo (2006) did a study on employee empowerment programs among international NGOs in the public health sector in Kenya. The study intended to identify the employee empowerment programs among international NGOs in the public health sector in Kenya and to determine the factors that influence the adoption of empowering programs in the sector. Another study by Gumato (2003) sought to establish the relationship between perceived empowerment and job satisfaction of employees in Commercial Banks in Kenya. Ndungu (2005) did a survey of managers' attitudes towards employee empowerment in selected oil companies in Kenya while Monari (2005) identified the factors that influence employee perception of empowerment with a focus on the staff of the University of Nairobi.

The studies that have been done on the City Council of Nairobi, on the other hand, have tackled issues other than employee empowerment. For instance, Mwove (2006) did a study on the operation strategies in solid waste management with a focus on the City Council of Nairobi. Gupta (1982) did a study on scheduling and control of transport labour and material in the City Council of Nairobi's Water Department. Lastly, Gathumbi (1997) did a study on the application of inventory models in drug inventory management for the City Council of Nairobi's Health 
Department. It is clear from the foregoing discussion that none of the studies on empowerment have been carried out on the City Council of Nairobi. Further, none of the studies has established the relationship between employee empowerment and firm performance in Kenya. Given the existing gap in knowledge and the underlying importance of employee contribution to the overall performance of firms, the proposed study aims at filling in this gap.

Studies done elsewhere, have established a strong relationship between employee empowerment and organizational performance. It is important for an organization to empower its employees if it expects to achieve its objectives. For instance, GeralisTerzivoski's (2003) study on Australian banks revealed that empowerment practices, when simultaneously implemented, are associated with greater employee well-being, productivity, performance, and service quality. It is in this context that this study seeks to find out if the CCN has empowered its employees and the extent to which this has influenced its performance.

\section{Objectives of the Study}

The objectives of this study was to:

1. Establish the extent to which the City Council of Nairobi had put in place employee empowerment programs

2. Determine the relationship between employee empowerment practice and the performance of the City Council of Nairobi.

\section{Contributions of the Study}

The findings of this study will be of benefit to various stakeholders.

a) Human Resource Practitioners.

The HR practioners will gain an understanding of how critical employee empowerment is to organizations and therefore recommend strategies to fast track the same as a source of competitive advantage for organizations.

b) Management in the City Council of Nairobi

The results of this study will be useful in terms of enlightening Management in the City Council of Nairobi on the importance of employee empowerment. The recommendations given shall help the Managers in increasing their investment in empowering employees.

c) Other Local Authorities

The findings of the study will be a useful resource by pointing out the importance of employee empowerment in Local Authorities. The link between employee empowerment practice and performance may not necessarily be confined to the Local Authorities sector thus the results may be a pointer towards what may happen in other sectors of the economy.

d) Other researchers

Other researchers and students of human resource management will find this study a useful guide in carrying out more research in this area and more discussions on the importance of employee empowerment in organizations 
PROBLEMS

OF MANAGEMENT

IN THE $21^{\text {st }}$ CENTURY

Volume 5, 2012

Research Methodology

\section{Research Design}

A case study is an in-depth investigation of an individual, institution or phenomenon (Mugenda and Mugenda, 2003). The primary purpose of a case study was to determine factors and relationships among the factors that have resulted in the behaviour under study. Since this study sought to establish the relationship between employee empowerment and performance of the City Council of Nairobi, a case study design was deemed the best design to fulfill the objective of the study.

\section{Data Collection}

The study used both primary and secondary data. The primary data was collected through a structured questionnaire administered on a drop and pick basis. The questionnaire had both open-ended questions and closed ended questions. The questionnaire was divided in two parts; part one focused on biographical data while part two addressed employee empowerment. Data on performance as measured by return on assets (ROA) was collected from secondary sources.

The population of interest comprised all the employees of the City Council of Nairobi. The City Council of Nairobi was picked since it is of the largest local authority in Kenya and is, therefore, more likely to engage in the best human resource practices. This was reinforced by the fact that council was the top performance contract for (2006/2007) financial year. A Sample of 60 employees, 4 from each of the 15 departments were randomly selected as respondents for the questionnaire.

\section{Characteristics of the Respondent}

Of the 60 questionnaires issued , 56 were filed and returned were edited for completeness and consistency. The study achieved a response rate of $93 \%$. The $7 \%$ non response rate was as a result of delay by the respondent in filling the questionnaire.

\section{Demographic Characteristics and Workers Profile}

The demographic information considered in this study for the staff of CCN included gender of the respondents, duration at the position currently held, level of education, age and marital status, departments worked, designation. These have been analyzed as follows:

\section{Gender}

The respondents were asked to indicate their gender; this was expected to guide the researcher on the conclusions regarding the congruence of respondents to the gender characteristics. The results as in the table 1 below show that a majority of the respondents were male at $55 \%$. To this extent, the findings can be generalized on the male respondents.

Table 1. Gender.

\begin{tabular}{|c|c|c|}
\hline Gender & Frequency & Percentage \\
\hline Male & 31 & 55 \\
\hline Female & 25 & 45 \\
\hline Total & 56 & \\
\hline
\end{tabular}

Source: City Council of Nairobi Reports 2008 
Stephen N. M. NZUVE, Tsala Halima BAKARI. The Relationship between Empowerment and Performance in the City Council of Nairobi

\section{Department Worked}

The respondents were asked to indicate the department they worked. This was also expected to guide the researcher in setting classifying the responses from each department. The results of the study show that a majority of the departments had the same number of respondents: particularly, administration, audit, city inspectorate, city treasurer, human resource and investigations and information analysis had four respondents each. City respondents were from education, health, legal affairs and public health department. The implication on the study is that varied responses from the different departments can adequately explore all the expected responses from the entire council.

\section{Designation}

The respondents were asked to indicate their designations in the departments they worked. The respondents had different designations such as administrative officers, city askaris (askari is a Swahili word for security personnel), clerical officers, copy typists, secretaries, clerks, cleaners, directors and messengers. The implication on the research is that the respondents were evenly distributed and therefore a variety of the responses were obtained.

\section{Length of Service in the Current Position}

The researcher sought to establish the years that the respondents had been in the positions stated. The findings in table 2 show that the number of years of service in the current position varies from a period of 1 year to over 10 years. $17.9 \%$ of the respondents had worked for a period of 4 to 6 years, $19.6 \%$ had worked for a period of 7 to 9 years and $46.6 \%$ had worked for over 10 years. The majority of the respondents $(82.1 \%)$ has worked in their current positions for over 4 years.

Table 2. Length of service in the current position.

\begin{tabular}{|c|c|c|c|}
\hline Length of service (years) & Frequency & Percent & Cumulative percent \\
\hline $1-3$ & 10 & 17.9 & 17.9 \\
\hline $4-6$ & 9 & 16.1 & 33.9 \\
\hline $7-9$ & 11 & 19.6 & 53.6 \\
\hline 10 and above & 26 & 46.4 & 100.0 \\
\hline Total & 56 & 100.0 & \\
\hline
\end{tabular}

Source: City Council of Nairobi Reports 2008

The results show that a majority had been in the organization for 10 years and above, others had also been on the council for 7 to 9 years. This implies that the majority of the respondents had enough experience to give acceptable responses to the study questions. 
PROBLEMS

OF MANAGEMENT

IN THE $21^{\text {st }}$ CENTURY

volume 5, 2012

\section{Education Level of Respondents}

The respondents were asked to indicate their level of education. This was in order to help the researcher judge the ability of the respondent to answer the questions as was set in the study. The results show that a majority of the respondents had adequate knowledge to enable them to respond to the questions asked in the study.

The findings presented in table 3 show that $1.8 \%$ of the respondents had gone up to primary school, $12.5 \%$ had secondary certificate, $46.4 \%$ had college certificate, $35.7 \%$ had university degrees (first degree) while $3.6 \%$ had other certificates which includes masters of business administration, higher diplomas, $\mathrm{CPA}(\mathrm{K})$ and $\mathrm{CPS}(\mathrm{K})$

Table 3. Educational Level of Respondents.

\begin{tabular}{|c|c|c|c|c|}
\hline Level of Education & Frequency & Job Designation & Percent & Cumulative Percent \\
\hline Primary Level & 1 & Cleaner & 1.8 & 1.8 \\
\hline Secondary & 7 & $\begin{array}{c}\text { Cleaner-1 } \\
\text { Messenger -3 } \\
\text { City Askari-3 } \\
\text { (Guard) }\end{array}$ & 12.5 & 14.3 \\
\hline $\begin{array}{c}\text { College Level (Certifi- } \\
\text { cate/Diploma) }\end{array}$ & 26 & & 46.4 & 60.7 \\
\hline University level & 20 & & 35.7 & 96.4 \\
\hline Others & 2 & & 3.6 & 100.0 \\
\hline Total & 56 & & 100.0 & \\
\hline
\end{tabular}

Source: City Council of Nairobi Reports 2008

\section{Age Bracket of Respondents}

The respondents' age was also to assist the researcher in judging the seniority of the respondents and to hint on the general experiences of the respondents with regard to social aspects. The results show that a majority of the respondents were aged between the ages of 34 to 41 years, followed by a significant percentage that had also attained ages between 42 to 49 years. The age composition shows that most of the respondents were of the senior age levels and therefore apart from their rich experiences, they could also appreciate the importance of the study.

The findings presented in table 4 show that $16.1 \%$ of the respondents were of age 26-33 years, $44.6 \%$ were between $34-41$ years of age, $26.8 \%$ were between $42-49$ years old and a few $(12.5 \%)$ were 50 years and above. On average the majority of the employees are between the age brackets of 34-49 years.

Table 4. Age bracket.

\begin{tabular}{|c|c|c|c|}
\hline Age Bracket (Years) & Frequency & Percent & Cumulative Percent \\
\hline $26-33$ & 9 & 16.1 & 16.1 \\
\hline $34-41$ & 25 & 44.6 & 60.7 \\
\hline $42-49$ & 15 & 26.8 & 87.5 \\
\hline 50 and above & 7 & 12.5 & 100.0 \\
\hline Total & 56 & 100.0 & \\
\hline
\end{tabular}

Source: City Council of Nairobi Reports 2008 
Stephen N. M. NZUVE, Tsala Halima BAKARI. The Relationship between Empowerment and Performance in the City Council of Nairobi

Marital Status

The respondents were asked to indicate their marital status. The results show that a majority of the respondents were married, this was represented by $87 \%$, and the rest were single. The implication is that for some interpersonal reasons, the conclusions may be drawn on the marital status as illustrated in table 5

Table 5. Analysis of marital status.

\begin{tabular}{|c|c|c|}
\hline Marital Status & Frequency & Percent \\
\hline Married & 49 & 87.5 \\
\hline Single & 7 & 12.5 \\
\hline Total & 56 & 100 \\
\hline
\end{tabular}

Data Analysis

The data was checked for accuracy and completeness. The analysis was done mainly using descriptive statistics such as mean scores, frequencies and percentages. Pearson product moment correlation technique was used to establish the strength and significance between empowerment and performance.

\section{Results of Research}

\section{Employee Empowerment Practices}

The respondents were asked to indicate the extent to which they agreed with the statements, as were listed in the questionnaire. The statements represented the characteristic practices of successful empowerment. The Likert scale of 1 to 5 was used, 1 represented strongly disagree while 5 represented strongly agree. The results as presented below shows that the respondents agree that they have mastered the skills necessary for their jobs and that their work is meaningful to them. The respondents neither agreed nor disagreed with the statements that they had control over the aspects of the job they were accountable for, that their work gives them ability to contribute to the success of the organization or that their position allowed career growth and development.

In addition, the respondent also neither agreed nor disagreed that they had significant opportunity for freedom and independence in doing their jobs. These were represented by mean scores of three. The respondents stated that they disagree to some extent with the statement that there is a clear system of handling employee discontent and that they normally get sufficient support to ensure they do their jobs.

Generally, the employee empowerment score in the City Council of Nairobi shows that the employees are empowered to a large extent. This is given by an average score of 3.546. These findings are summarized in Table 6. 
PROBLEMS OF MANAGEMENT IN THE $21^{\text {st }}$ CENTURY Volume 5, 2012

\section{Table 6. Employee Empowerment Practices.}

\begin{tabular}{|l|c|}
\hline Empowerment Practices & Mean Score \\
\hline I have mastered skills necessary for my job & 4.3214 \\
\hline The work I do is meaningful to me & 4.1250 \\
\hline I have control over those aspects of my job for which I am accountable & 4.0000 \\
\hline My work gives one ability to contribute to the success of my organization & 3.8214 \\
\hline My impact on what happens in my department is large & 3.8214 \\
\hline My supervisor encourages team work & 3.8036 \\
\hline My supervisor delegates authority to me & 3.6964 \\
\hline I have significant autonomy in determining how I do my job & 3.6964 \\
\hline My position allows for career growth and development & 3.6071 \\
\hline I have a significant opportunity for independence and freedom in how I do my job & 3.5357 \\
\hline In my organization, employees are encouraged to take quick action to improve service quality & 3.5357 \\
\hline I always get support and feedback from my superiors and my co- workers & 3.4821 \\
\hline I am always informed of what is going on in the organization & 3.1964 \\
\hline These are enough flexibility and independence allowed in the organization & 3.1429 \\
\hline I am encouraged to develop creative and innovative ideas & 3.1250 \\
\hline There is a clear system of handling employee discontent & 2.8750 \\
\hline I normally get sufficient resources to do my job & 2.6250 \\
\hline
\end{tabular}

\section{Relationship between Empowerment and Performance}

A regression analysis was carried out to establish the effect of employee empowerment on the financial performance of the City Council of Nairobi. The financial periods covered in the study were 2005, 2006 and 2007. The financial data for these periods were found from the statements of accounts of the council for the period. Employee empowerment was the independent variable while performance, measured by return on assets, was the dependent variable. Given the nature of financial reporting of councils, the ratio for return on assets was determined by the ratio of income to the assets of the organization.

Return on Assets $=\quad$ Income Assets

Table 7 shows the calculation of ROA for the Years 2005, 2006, and 2007. 
Stephen N. M. NZUVE, Tsala Halima BAKARI. The Relationship between Empowerment and Performance in the City Council of Nairobi

PROBLEMS

OF MANAGEMENT

IN THE $21^{\text {st }}$ CENTURY

Volume 5, 2012

Table 7. Return on Assets.

\begin{tabular}{|c|c|c|c|c|c|}
\hline Mean & & & & & \\
\hline 4.3214 & & 2007 & 2006 & 2005 & Average \\
\hline 4.125 & Income & 2601200 & 886331 & 964969 & 1484167 \\
\hline 3.875 & Assets & 10559275 & 10907553 & 7499336 & 9655388 \\
\hline 3.8214 & ROA & 24.63427 & 8.125846 & 12.86739 & 15.20917 \\
\hline 3.8214 & & & & & \\
\hline 3.8036 & & & & & \\
\hline 3.6964 & & & & & \\
\hline 3.6964 & & & ROA & EMP & \\
\hline 3.6071 & & 2007 & 24.63427 & 3.5 & \\
\hline 3.5357 & & 2006 & 8.125846 & 1.2 & \\
\hline 3.5357 & & 2005 & 12.86739 & 1.8 & \\
\hline 3.4821 & & & & & \\
\hline 3.1964 & & & & & \\
\hline 3.1429 & & & & & \\
\hline 3.125 & & & & & \\
\hline 2.875 & & & & & \\
\hline 2.625 & & & & & \\
\hline
\end{tabular}

Regression analysis of the performance of the City Council of Nairobi (Dependent Variable) versus employee empowerment (Independent variable) was performed. The analysis indicated that $99.7 \%$ of the changes in performance of $\mathrm{CCN}$ were explained by the employee empowerment (R square).

Using hypothesis testing on the established model of: $\mathrm{Y}=0.158+6.85$, employee empowerment at $5 \%$ significance level, the results show that the p-value of $0.04>0.05$ hence there exists a linear regression relationship.

The predictor $\mathrm{p}$-value of 0.036 is also less than 0.05 hence employee empowerment is positively linearly related with the performance on the $\mathrm{CCN}$.

The established model can therefore be recommended for forecasting, that is employee empowerment has a significant role to play in the performance of the CCN.

Thus the study found that there is a very strong positive correlation between employee empowerment and performance. As shown, the correlation coefficient, $\mathrm{R}$, was found to be 0.997 indicating that employee empowerment accounted for $99.7 \%$ of the variance in performance as measured by ROA.

\section{Discussion and Conclusion}

The study sought to establish the extent to which $\mathrm{CCN}$ had put in place employee empowerment programs and to determine the relationship between employee empowerment practice and the performance of the City Council of Nairobi. In relation to the empowerment practices, it can be concluded that the employees of $\mathrm{CCN}$ have been able to master the skills necessary for the job and that their work was meaningful to them. The most important aspects 
PROBLEMS

OF MANAGEMENT

IN THE $21^{\text {st }}$ CENTURY

Volume 5, 2012

of a job description are that an employee must have the requisite skills, knowledge and understanding of the job roles and expectations to be able to be given authority with minimum supervision.

The study also concludes that employee empowerment had a significant positive influence on the performance of the City Council of Nairobi. This is because the regression analysis indicated that $99.7 \%$ of the variance in performance as measured by ROA was as a result of employee empowerment.

The study recommends that to improve empowerment, the City Council of Nairobi needs to undertake various steps and improve on certain aspects of the work environment. In particular a serious consideration needs to be given to the establishment of systems for handling employee discontent and provision of adequate resources for each job position.

Employees' discontent directly impacts on output. The analysis shows that employees were not satisfied with the current system of handling discontent. It is therefore recommended that a new system be put in place to address the issues which were not being fully addressed by the current system. This would require the development of policy on handling employees' discontent if there is none in place, and if it exists, then a thorough review of the policy needs to be done.

The CCN further needs to address job autonomy and opportunity for growth and development for the well performed job roles. Team work and delegation of authority allows employees to be prepared for bigger roles. There is a need for a program to address delegation and teamwork.

Employee empowerment process should be fully supported by top management. As witnessed in the analysis, top management support was lacking. The study also recommends that for the City Council of Nairobi to have better results in terms of revenue collection, employee empowerment needs to be considered as a priority because it has significance influence on its performance. Failure to look into the issues of employee empowerment may result in adverse effects on its performance.

In view of the results findings, it is recommended that all supervisors should improve on their communication speed and mode. This can be done by organizing a training course on the effectiveness of prompt feedback to the overall performance of the organization as well as the other aspects of communication.

\section{Recommendations for Further Research}

The study confined itself to City Council of Nairobi. Similar research therefore should be replicated in other city councils, municipal council sand county councils which have also implemented the employee empowerment process and the results be compared so as to establish whether there is consistency among the councils.

\section{References}

Adler, P. (1993). Time and motion regained. Harvard Business Review, January/February, 97-108

Armstrong, M. (2006). A handbook of Human Resource Management Practice, $10^{\text {th }}$ edition, Gopson Papers Ltd, Noida India.

Barrie, G. D. (2003). Managing Quality. Blackwell Publishers, Australia.

Beardwell, et al (2004). Human Resource Management, 4th edition. Pearson education Ltd, UK.

City Council of Nairobi (2008). Annual Reports. Nairobi.

Cogner, J. A., Kanungo, G. N. (1998). The empowerment process: integrating theory and practice. Academy of Management Review, 13 (3), 471-482.

Cunningham, I., Hyman, J., Baldry, J. (1996). Empowerment: the power to do what? Industrial Relations Journal, 27 (2), 143-154. 
Stephen N. M. NZUVE, Tsala Halima BAKARI. The Relationship between Empowerment and Performance in the City Council of Nairobi

$\mid$\begin{tabular}{l} 
PROBLEMS \\
OF MANAGEMENT \\
IN THE 21 $1^{\text {st }}$ CENTURY \\
Volume 5, 2012 \\
\hline 97
\end{tabular}

Denham, N., Ackers, P., Travers, C. (1997). Doing yourself out of a job? How middle managers cope with empowerment. Employee Relations, 19 (2), 147-159.

Gathumbi, S. N. (1997). Application of Inventory Models in Drug Inventory Management: The Case of NCC (Nairobi City Council) Health Services. Unpublished MBA Thesis, University of Nairobi.

Gumato, U. (2003). Survey of the Relationship between the Perceived Empowerment and Job Satisfaction of Employees in Commercial Banks in Nairobi. Unpublished MBA Thesis, University of Nairobi.

Gupta, H. V. (1982). Scheduling and Control of Transport Labor Force and Material in Nairobi City Council Water Department. Unpublished MBA Thesis, University of Nairobi.

Hales, C. (2001). Does it matter what managers do? Business Strategy Review, 12 (2), 50-58.

Hechanova, M., Regina, M., Alampay, Ramon, B. A., Edna, P. F. (2006). Psychological empowerment, job satisfaction and performance among Filipino service workers. Asian Journal of Social Psychology, 9, 72-78.

Holt, G. D., Love, P. E. D., Nesan, L. J. (2000). Employee empowerment in construction: an implementation model for process improvement. Team Performance Management: An International Journal, 6 (3), 47-51.

Johnson, P. R. (1994). Brains, heart and courage: keys to empowerment and self-directed leadership. Journal of Managerial Psychology, 9 (2), 17-21.

Lashley, C. (1999). Employee empowerment in services: a framework for analysis. Personal Review, 28 (3), 169-91.

Lawler, E. E., Mohram, S. A., Ledford, G. E. (1992). Employee Involvement and Total Quality Management: Practices and Results in Fortune 1000 Companies. Jossey-Bass, San Francisco, CA.

Lee, M., Koh, J. (2001). Is empowerment really a new concept? International Journal of Human Resource Management, 12 (4), 684-695.

Lydia, K. O. (2006). Employee Empowerment Programs Among International NGOs in the Public Health Sector in Kenya. Unpublished MBA Thesis, University of Nairobi.

Menon, S. T. (1995). Employee Empowerment: Definition, Measurement and Construct Validation. McGill University, Montreal.

Monari, F. (2007). Factors Influencing Employee Perception on Empowerment: A Case Study of the UoN Staff, Unpublished MBA Thesis, University of Nairobi.

Mondros, J. B., Wilson, S. M (1994). Organising for Power and Empowerment. Colombia University Press, New York, N.Y.

Monica, M. (2006). Operation Strategies in Soild Waste Management: The Case of Nairobi City Council. Unpublished MBA Thesis, University of Nairobi.

Mullins, L. J., Peacock, A. (1991). Managing through people: regulating the employment relationship. Administrator, December, 45-55.

Ndungu, G. W. (2005). A survey of Managers Attitudes Towards Employee Empowerment in Selected Oil Companies in Kenya. Unpublished MBA Thesis, University of Nairobi.

Pastor, J. (1996). Empowerment: what it is and what its not. Empowerment in Organizations, 4 (2), 5-7.

Psoinos, A., Smithson, S. (2002). Employee empowerment in manufacturing: A study of organization in the UK. New Technology, Work and Employment, 17 (2), 132-148.

Rosenthal, P., Hill, S., Peccei, R. (1997). Checking out service: evaluating excellence, HRM, and TQM in retailing. Work, Employment and Society, 11 (3), 481-503.

Russ, D. E., Millam, E. R (1995). Executive commentary-empowerment a matter of degree? Academy of Management Executive, 9 (3), 29-31.

Storey, J. (1992). Managing of Human Resources. Blackwell Publishers Ltd, UK.

Thomas, K. W., Velthouse, B. A. (1990). Cognitive elements of empowerment. Academy of Management Review, 15, 66-81.

Torrington, et al (2005). Human Resource Management, $6^{\text {th }}$ edition. Pearson Educational Ltd, UK.

Tulloch, S. (1993). The Reader's Digest Oxford Wordfinder. Clarendon, Oxford.

Vogt, J. F., Murrell, K. L. (1990). Empowerment in Organizations: How to Spark Exceptional Performance. University Associates, San Diego, CA.

Wilkinson, A. (1998). Empowerment: theory and practice. Personal Review, 27 (1), 50-56. 
PROBLEMS

OF MANAGEMENT

IN THE $21^{\text {st }}$ CENTURY

Volume 5, 2012

Advised by Ivars Muzis, Riga Teacher Training and Educational Management Academy,

Latvia

Received: August 22, 2012

Accepted: October 22, 2012

Stephen N. M. Nzuve

BSc, MSc, Senior Lecturer, Department of Business Administration, Lower Kabete Campus, University of Nairobi, P. O. Box 30197 - 00100, Nairobi, Kenya.

E-mail: snmnzuve@uonbi.ac.ke

Website: http://archive.uonbi.ac.ke/profiles/?id=97530

Tsala Halima Bakari

MSc., University of Nairobi, School of Business, P.O Box 30197-00100, Nairobi, Kenya. 